\title{
Optimizing Soil Moisture and Nitrogen Use Efficiency of Some Maize (Zea mays) Varieties under Conservation Farming System
}

\author{
Simunji Simunji ${ }^{1}$, Kalaluka L. Munyinda ${ }^{1}$, Obed I. Lungu ${ }^{2}$, Alice M. Mweetwa ${ }^{2} \&$ Elijah Phiri ${ }^{2}$ \\ ${ }^{1}$ Department of Plant Science, School of Agriculture Sciences, The University of Zambia, P.O Box, 32379 \\ Lusaka, Zambia \\ ${ }^{2}$ Department of Soil Science, School of Agriculture Sciences, The University of Zambia, P.O Box, 32379, \\ Lusaka, Zambia \\ Correspondence: Simunji Simunji, Department of Plant Science, School of Agriculture Sciences, The University \\ of Zambia, Lusaka, Zambia. Tel: 260-1-250-587. E-mail: simunji@ yahoo.co.uk
}

Received: June 29, 2018 Accepted: July 13, 2018 Online Published: August 9, 2018

doi:10.5539/sar.v7n4p42 URL: https://doi.org/10.5539/sar.v7n4p42

\begin{abstract}
In Zambia, small holder farmers depend on producing maize (Zea mays), which is a major staple food for many Zambians. Maize productivity among the smallholder farmers is quite low, giving only 2.3 tons per hectare. The low yields are attributed to insufficient and erratic rain fall, low soil fertility, and poor farming practices. Therefore, the objective of this study was to evaluate the performance of maize genotypes for nitrogen use efficiency and soil moisture utilisation under conservation farming system. The trials were carried out at two sites with different soil types. Three maize varieties i.e. ZMS 606, GV 640 and GV 635 were evaluated in maize - cowpea rotation. Four cowpea varieties used for rotation with maize, i.e. Bubebe Lutembwe, BB 14-16-2-2 and LT 11-3-3-12. BB 14-16-2-2 and LT 11-3-3-12 are mutation-derived lines of Bubebe and Lutembwe cowpea parent varieties respectively. The experimental design used was split plot with three replications. The NUE was significantly $(\mathrm{P}<0.05)$ higher in $\mathrm{CF}$ and accounted for $27 \%$ and $15 \%$ more than conventional farming system which valued $17 \%$ and $3 \%$ at Chisamba and Batoka, respectively. while soil moisture content was higher at Batoka than Chisamba in CF system. ZMS 606 and GV 640 varieties were superior over GV 635 for NUE. Cowpea variety BB 14-16-2-2 significantly increased NUE of maize varieties. Therefore, smallholder farmers in Zambia can increase maize productivity in maize - cowpea rotation system due to the increased NUE. Recommendations are made for farmers to select improved nitrogen efficient maize varieties to optimize productivity of maize in conservation farming system.
\end{abstract}

Keywords: conservation farming, nitrogen use efficiency, rotation, soil moisture content

\section{Introduction}

About $80 \%$ of the one million five hundred smallholder farmers in Zambia depend on producing maize (Zea mays) which is a major staple food for well over $90 \%$ of the Zambians. Productivity of the maize crop among the smallholder farmers over the years has become quite low giving a national average yield of 2.3 tons per hectare (Indaba Agricultural Policy Research Institute [IAPRI], 2015). The major causes of low yields countrywide are attributed to prolonged droughts, erratic rain fall pattern, low soil fertility, insufficient plant nutrients and poor farming practices (Cakir, 2004).

The soil fertility status in several parts of Zambia is also generally low and low soil fertility status in most cases could be caused by poor farming practices such as conventional farming or inherently unproductive soils at Smallholder farms. The evidence on soil fertility improvement by cover crop was explained by Karsky, Patrice and Salini (2003) that cowpea increases nitrogen in the soil up to $80 \mathrm{~kg} \mathrm{~N} \mathrm{ha}^{-1 .}$ Being a food legume, cowpea provides the needed proteins in rural households through both grain and leaves that are used as relish. Cowpea also plays a multipurpose role of potential to be used for human food; livestock feed and weed control (Rao \& Mathuva, 2000).

Fertilizer prices have in the past few years almost become unaffordable by the majority of the smallholder farmers (Aagaard, 2011). Despite the Government subsidies on fertilizers for smallholder farmers, yields of the crop do not seem to improve. 
There is much evidence that climate change is also likely to lead to decreases in Global efficiency and resilience of agriculture production while at same time being confronted with increasing demand from a growing population (Food and Agriculture Organization [FAO], 2010). Measures that promote climate change mitigation there by contain the potential to strongly co-benefit adaptation and food security, if targeted in an adequate way.

In the advent of Climate change (CC) where rain fall pattern have reduced and temperatures increased, use of climate smart agriculture technologies could improve maize productivity among smallholder farmers in Zambia. Climate Smart Agriculture refers to all farming practices that contribute to improve maize productivity. FAO (2010) defined Climate Smart Agriculture (CSA) as a farming system that seeks to increase productivity and food security sustainably, strengthen farmers' resilience to climate variability and change and remove greenhouse gases emissions. Improving soil quality is one of the fundamental activities of CSA, as higher quality soils are better able to retain moisture and reduce run off-two important features in responding to drought and flooding (Peter \& Bram, 2010).

Therefore, use of improved maize varieties tolerant to low nitrogen and water in the nitrogen and water stressed environment under the minimum tillage with maize- cowpea rotation could contribute to increased NUE of maize and adoption of the system in Zambia. This makes alternative option for improving maize production by the smallholder farmers. Maize- Cowpea Rotation involves planting of maize crop after the cowpea legume crop and this technology facilitates improvement of maize productivity through increased soil fertility from cowpea nitrogen fixation (Verhulst et al., 2010). Sumanta et al., 2013 reported that conservation agriculture increased use efficiency of nitrogen by $11 \%$ over conventional system.

In order to respond to these challenges, the experiment was established during the 2014/2015, 2015/2016 and 2016/2017 growing seasons whose main objective was to increase maize productivity in conservation farming system, while the specific objectives of this study were (i) to evaluate the performance of maize genotypes for nitrogen use efficiency; (ii) to evaluate soil moisture utilisation and (iii) to identify maize - cowpea combinations with high NUE and soil moisture utilization for high maize productivity under conservation farming system.

\section{Materials and Methods}

The study focused on evaluating improved selected maize and cowpea genotypes in Zambia for effective uptake and partitioning of nitrogen under Maize- cowpea rotation system.

\subsection{Location}

The study was conducted at two sites which were Chisamba of Chibombo district on coordinates S $14.96783^{\circ}$, E 028.09408 ${ }^{\circ}$; and Batoka of Choma district on coordinates S16.79993 ${ }^{\circ}$, E $027.20181^{\circ}$ in region II of the Zambian agro-ecological zones but having different soil types. Chisamba has clay loam while Batoka has loamy sand soils.

\subsection{Source of Seeds (Maize and Cowpea Varieties)}

Three maize varieties were evaluated for water and nitrogen use efficiency. Two (2) maize varieties (GV 640 and GV 635) having good traits of water and nitrogen use efficiency were selected from Zambia Agricultural Research Institute (ZARI) maize breeding programme. The third variety was ZMS 606 from Zamseed Company and is mostly purchased by small holder farmers for Region II of the Zambian agro-ecological zone. The four cowpea genotypes were evaluated for improved Biological nitrogen fixation and maize productivity in the maize- cowpea rotation. Cowpea genotypes were two parents (Bubebe and Lutembwe) and two mutants (BB 14-16-2-2 and LT 11-3-3-12) one from each parent obtained from the University of Zambia School of agricultural sciences, Department of Plant Science.

\subsection{Experimental Design}

The experimental design used was a split plot arranged in and replicated three times. The main treatments were two different farming systems adjacent to each other. (a) Conservation farming system (CF) which included minimum tillage by ox- drawn ripping, maize-cowpea rotation and crop residue retention. (b) Conventional farming system (CONV) which involved complete tillage of soil by ox-drawn ploughing, mono-cropping and removal of crop residues after harvesting. The sub treatments were three maize varieties and these were ZMS 606(M1), GV 640(M2) and GV 635(M3).

\subsection{Trial Establishment}

In year 1 (2014/15 season) Maize varieties in the conventional farming systems and cowpea varieties in the conservation farming systems were evaluated. The trials in year 1 aimed at establishing the rotation system for 
maize- cowpea in the CF and mono cropping system for maize in the conventional system. Four cowpea genotypes were analyzed for productivity and potential for rotation with maize on the already established CA field plot (Field plot that had received minimum tillage and rotation for at least 3 years.

In year $2(2015 / 2016)$ season maize varieties were assessed for water and nitrogen use efficiency in the maize cowpea rotation system on the four cowpea genotypes in the CF field as compared to same maize varieties under maize mono cropping system (conventional). ${ }^{15} \mathrm{~N}$ labeled urea which was diluted from 5.18 atom\% ${ }^{15} \mathrm{~N}$ to 2.58 atom $\%{ }^{15} \mathrm{~N}$ was applied to all treatment plots on $1.5 \mathrm{~m}^{2}$ area at four weeks after planting maize and two weeks after planting cowpeas for determination of nitrogen uptake by both crops. The access tubes for moisture content reading were inserted per each plot. A diviner 2000 was used to measure moisture content up to $1.0 \mathrm{~m}$ depth once per week for a period of 12 weeks and started at five weeks after planting maize crop at Chisamba site. While at Batoka, soil moisture content was measured with $\mathrm{HH} 2$ soil meter using auger marked at $15 \mathrm{~cm}, 30 \mathrm{~cm}, 40 \mathrm{~cm}$ and $60 \mathrm{~cm}$ depth. Four (4) rows of $6 \mathrm{~m}$ length spaced at $0.75 \mathrm{~m}$ were marked and planted with maize at an intra -row spacing of $0.25 \mathrm{~m}$. Each plot of cowpea crop had 12 rows of $6 \mathrm{~m}$ length spaced at $0.75 \mathrm{~m}$. Cowpea seed was drilled along the ripped furrows to about $7 \mathrm{~cm}$ between seeds. 2 guard rows at each end of the block for both crops were included.

\subsection{Crop Management}

Maize seed was planted at $25 \mathrm{~cm}$ between stations in the ripped furrows. Cowpeas used for rotation with maize was drilled along the ripped furrows at seed rate of $30 \mathrm{~kg} / \mathrm{ha}$. Fertilizer nutrients were applied at $112 \mathrm{kgha}^{-1}$ Nitrogen, $40 \mathrm{kgha}^{-1}$ Phosphorus and $20 \mathrm{kgha}^{-1}$ Potassium on maize crop. Basal Fertilizer nutrients $\left(20 \mathrm{kgha}^{-1}\right.$ Nitrogen, $40 \mathrm{kgha}^{-1}$ Phosphorus and $20 \mathrm{kgha}^{-1}$ Potassium) application were at planting and top dressing $92 \mathrm{kgha}^{-1}$ Nitrogen was at vegetative stage, five weeks after planting. Cowpea crop received basal dressing only of 20 $\mathrm{kgha}^{-1}$ Nitrogen, $40 \mathrm{kgha}^{-1}$ Phosphorus and $20 \mathrm{kgha}^{-1}$ Potassium. Two separate sprays against pests and diseases were made on cowpeas plots. The first control was at two weeks after cowpea emergency and the second at flowering stage. At planting, weed control started with Glyphosate spray targeting emerged weeds in the trial field. The next weeding was done manually twice at two and four weeks after planting the crop. Two rows of maize crop were harvested for biomass and grain yield analysis. $0.5 \mathrm{~m}$ was discarded at each end of the row. Two plants and cobs were sampled from ${ }^{15} \mathrm{~N}$ treated rows for analysis of $\mathrm{N}$ and $\mathrm{C}$. Eight rows of cowpea were harvested for dry biomass and grain yield analysis.

\subsection{Data Analysis}

The data collected were agronomic maize and cowpea yields, $\% \mathrm{~N}$ and atom $\%{ }^{15} \mathrm{~N}$ for maize. Nitrogen use Efficiency was calculated as a percentage of nitrogen uptake in maize grain to the Nitrogen applied (International Atomic Energy Agency [IAEA], 2008). Data were analysed with Genstat $18^{\text {th }}$ edition.

\section{Results and Discussions}

\subsection{Soil Characteristics of the Test Sites}

The results of the soil chemical and physical properties at the experimental sites before planting are represented in Table1 and 2. Between the two sites, Chisamba had more fertile soil with higher soil pH, organic matter and nitrogen content than Batoka. The Batoka site however, had higher bulk density, soil water content at field capacity and plant available than Chisamba hence soil texture at Batoka was described as loamy sand and Chisamba was Clay loam. The results were in agreement with Hamza and Anderson (2003) who found that Cation exchange capacity and exchangeable calcium increased more on the clayey than on the sandy soil.

Table 1. Baseline Soil chemical properties of the sites

\begin{tabular}{lllllllllll}
\hline Farming Systems & Site & Depth & $\mathrm{pH}$ & $\mathrm{OM}$ & $\mathrm{N}$ & $\mathrm{P}$ & $\mathrm{K}$ & $\mathrm{Ca}$ & $\mathrm{Mg}$ & $\mathrm{Zn}$ \\
\hline CONV & & $\mathrm{Cm}$ & & $\%$ & & $\mathrm{mg} / \mathrm{kg}$ & $\mathrm{cmol} / \mathrm{kg}$ & & $\mathrm{mg} / \mathrm{kg}$ \\
CONV & Batoka & $0-15$ & 4.12 & 1.68 & 0.08 & 17.4 & 0.1 & 1.27 & 0.29 & 0.04 \\
$\mathrm{CF}$ & Batoka & $15-30$ & 4.31 & 0.96 & 0.06 & 14.62 & 0.08 & 1.78 & 0.37 & 0.06 \\
$\mathrm{CF}$ & Batoka & $0-15$ & 3.8 & 0.64 & 0.03 & 34.06 & 0.1 & 1.66 & 0.19 & 0.24 \\
$\mathrm{CONV}$ & Batoka & $15-30$ & 3.71 & 1.12 & 0.03 & 37.88 & 0.08 & 0.93 & 0.11 & 0.14 \\
CONV & Chisamba & $0-15$ & 6.17 & 0.72 & 0.05 & 17.92 & 1.04 & 10.9 & 5.48 & 0.28 \\
$\mathrm{CF}$ & Chisamba & $15-30$ & 6.2 & 2.72 & 0.09 & 17.86 & 0.78 & 10.92 & 5.76 & 0.12 \\
$\mathrm{CF}$ & Chisamba & $0-15$ & 5.49 & 3.2 & 0.05 & 18.86 & 1.11 & 8.59 & 4.4 & 0.28 \\
& Chisamba & $15-30$ & 5.58 & 2.72 & 0.08 & 13.15 & 0.83 & 8.98 & 5.01 & 0.20 \\
\hline
\end{tabular}


Table 2. Soil physical properties of the sites

\begin{tabular}{lccccccccc}
\hline Farming Systems & Site & Bulk Density & FC $\theta \mathrm{v}$ & PWP $\theta \mathrm{v}$ & PAW $\theta \mathrm{v}$ & Sand & Clay & Silt & Texture \\
\hline CONV & & $\mathrm{g} / \mathrm{cm} 3$ & $\%$ & $\%$ & $\%$ & $\%$ & $\%$ & $\%$ & \\
CONV & Batoka & 1.37 & 29.04 & 6.03 & 23.01 & 82 & 6.8 & 11.2 & Loamy Sand \\
CF & Batoka & 1.4 & 29.08 & 4.43 & 24.66 & 82 & 6.8 & 11.2 & Loamy Sand \\
CF & Batoka & 1.37 & 35.73 & 5.22 & 30.51 & 82 & 6.8 & 11.2 & Loamy Sand \\
CONV & Batoka & 1.36 & 43.16 & 14.74 & 28.42 & 82 & 6.8 & 11.2 & Loamy Sand \\
CONV & Chisamba & 1.12 & 27.93 & 10.77 & 17.16 & 46 & 24.8 & 29.2 & Loam \\
CF & Chisamba & 1.1 & 18.68 & 4.96 & 13.72 & 42 & 30.8 & 27.2 & Clay Loam \\
CF & Chisamba & 1.14 & 18 & 6.28 & 11.72 & 42 & 30.8 & 27.2 & Clay Loam \\
& Chisamba & 1.11 & 15.86 & 4.41 & 11.45 & 40 & 34.8 & 25.2 & Clay Loam \\
\hline
\end{tabular}

\subsection{Cowpea Dry Biomass Yield}

Performance of cowpea genotypes on the dry biomass and grain yield varied between sites and among genotypes. Chisamba site $(\mathrm{CHBIO})$ produced $2802 \mathrm{~kg} \mathrm{ha}^{-1}$ of cowpea dry biomass which was significantly $(\mathrm{P}<0.05)$ higher than the dry biomass at Batoka site (BK BIO) with 1188 $\mathrm{kg} \mathrm{ha}^{-1}$ during 2014/15 growing season (Figure 1). Similar trend of dry biomass yield was observed in the second growing season (2015/2016) where the yield of cowpea dry biomass was $4897 \mathrm{~kg} \mathrm{ha}^{-1}$ at Chisamba and $1753 \mathrm{~kg} \mathrm{ha}^{-1}$ at Batoka. The cowpea genotypes $\mathrm{C} 1$ (Lutembwe) and C3 (LT 11-3-3-12, produced an average of 3650 $\mathrm{kg} \mathrm{ha}^{-1}$ dry biomass yield and was significantly $(\mathrm{P}<0.001)$ more than yield of cowpea genotypes C2 (Bubebe) and C4 (BB 14-16-2-2) by $49 \%$ at Chisamba. However, at Batoka, cowpea $\mathrm{C} 1$ and $\mathrm{C} 3$ had an advantage over $\mathrm{C} 2$ on dry biomass yield. The higher cowpea dry biomass yield obtained at Chisamba could be attributed to relatively good soil physical and chemical properties as compared to loamy sand soils of Batoka. Cowpea dry biomass is important for improving soil fertility when the crop residue decompose (Verhulst et al., 2010).

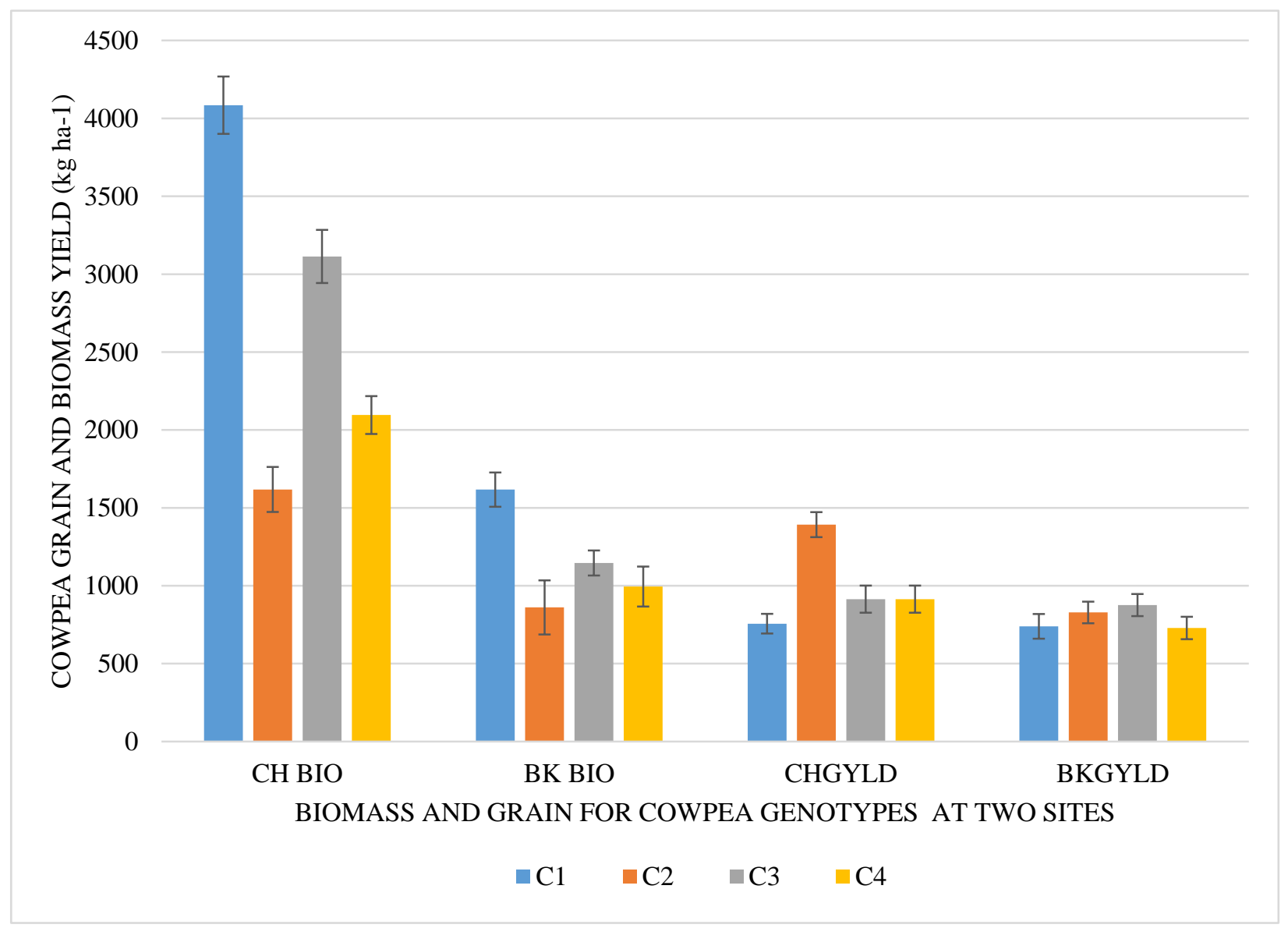

Figure 1. Cowpea dry biomass and grain yield at Chisamba and Batoka sites 
Table 3. Cowpea dry biomass nutrient content

\begin{tabular}{llllllll}
\hline \multicolumn{7}{c}{ Cowpea dry biomass nutrient content } \\
\hline Cowpea Genotypes & $\mathrm{Ca} \%$ & $\mathrm{~K} \%$ & $\mathrm{Mg} \%$ & $\mathrm{~N} \%$ & $\mathrm{P} \%$ & Zn ppm & $\mathrm{Mn} \mathrm{ppm}$ \\
\hline Lutembwe & 0.127 & 3.057 & 0.283 & 0.63 & 0.290 & 217 & 1011 \\
Bubebe & 0.130 & 1.673 & 0.333 & 2.14 & 0.277 & 300 & 790 \\
LT 11-3-3-12 & 0.123 & 3.100 & 0.247 & 2.59 & 0.283 & 250 & 857 \\
BB 14-16-2-2) & 0.163 & 3.183 & 0.243 & 4.53 & 0.253 & 306 & 970 \\
LSD $(0.05)$ & 0.0988 & 0.6744 & 0.789 & 0.954 & 0.0821 & 117.3 & 264.5 \\
Pr & 0.745 & 0.004 & 0.095 & $<0.001$ & 0.725 & 0.793 & 0.252 \\
CV & 36.4 & 12.3 & 14.3 & 19.3 & 14.9 & 21.9 & 14.6 \\
\hline
\end{tabular}

\subsection{Nitrogen Use Efficiency}

Nitrogen Use Efficiency (NUE) by maize genotypes was measured as a percentage ratio of nitrogen uptake in maize grain to the amount of nitrogen applied as ${ }^{15} \mathrm{~N}$ label. The NUE was significantly $(\mathrm{P}<0.05)$ found higher in CF than CONV system. High NUE in CF system could be as a result of crop rotation of maize and cowpeas that contributed to soil physical and chemical properties improvement. The results are in agreement with Verhulst, François, Grahmann, Govaerts and Cox (2014) who stated that crop monoculture has negative effects on yield and NUE and positive effects if legumes are included in the rotation. Nitrogen uptake in the CF was more compared to CONV and Maize genotype ZMS 606 (M1) expressed highest NUE at both sites GV 635 at Chisamba (Figure 2). This implies that there is genetic variation for nitrogen use efficiency among the maize genotypes used in the study. Therefore, development of new cultivars with higher NUE, coupled with best management practices such as conservation farming will contribute to sustainable agricultural systems that protect and promote soil, water and air quality(Baligar, Fageria, \& He, 2007).
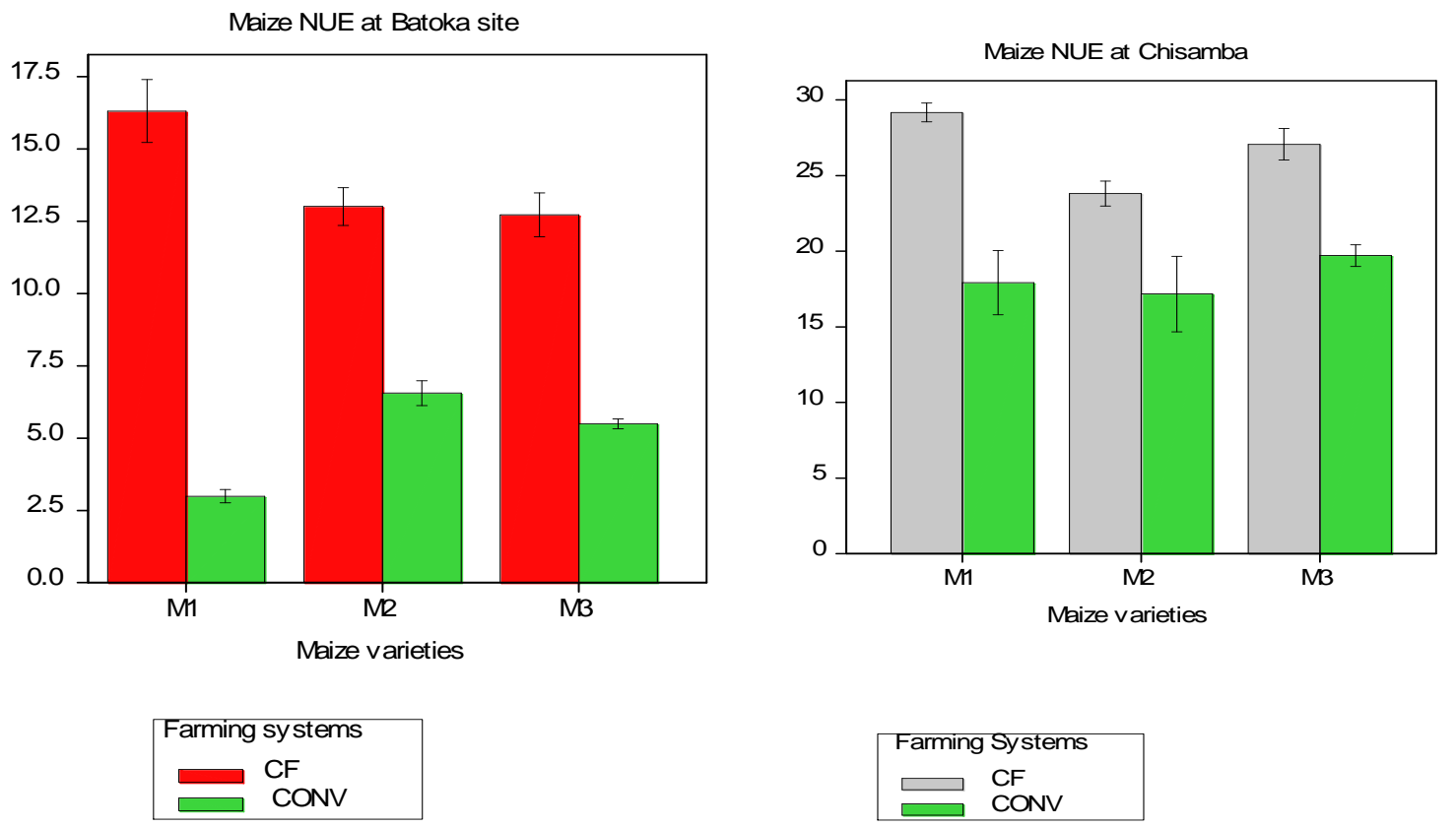

Figure 2. Nitrogen Use Efficiency in maize grain production under conservation and conventional farming systems at Chisamba (left) and Batoka (right) sites

\subsection{Soil Moisture Utilization}

The soil moisture content during the crop growth showed variations between CF and CONV farming systems. Batoka site which has loamy sand soils recorded higher water content in CF with $11.9 \%$ than in CONV which was $9.1 \%$ at $40 \mathrm{~cm}$ depth 8 weeks after planting. Neither maize nor cowpea genotypes had influence on the availability of moisture at Batoka. Chisamba site, however had more moisture content in CONV (56.2\%) compared to $\mathrm{CF}(46.1 \%)$. Chisamba site showed significant interaction $(\mathrm{P}=0.005)$ between farming systems and maize genotypes. ZMS 640 (M2) significantly conserved more water than ZMS 606 (M1) and GV 635(M3) in 
CF system. The results have indicated that amount of water uptake by maize plant depends not only on farming system but also on the genotype (Hansakar, 1996). Considering the high maize grain yield produced by GV 640 in the CF, it means that water use efficiency (WUE) could be highest for GV 640 compared to other two maize genotypes (Tahar, 2010). The lower moisture content in the CF could have been attributed to high water uptake by vigorous growing maize crop (Figure 3 and 4). These results were in agreement with Esser, 2017, who stated that moisture content in the CF maize crop was less as compared to CONV.

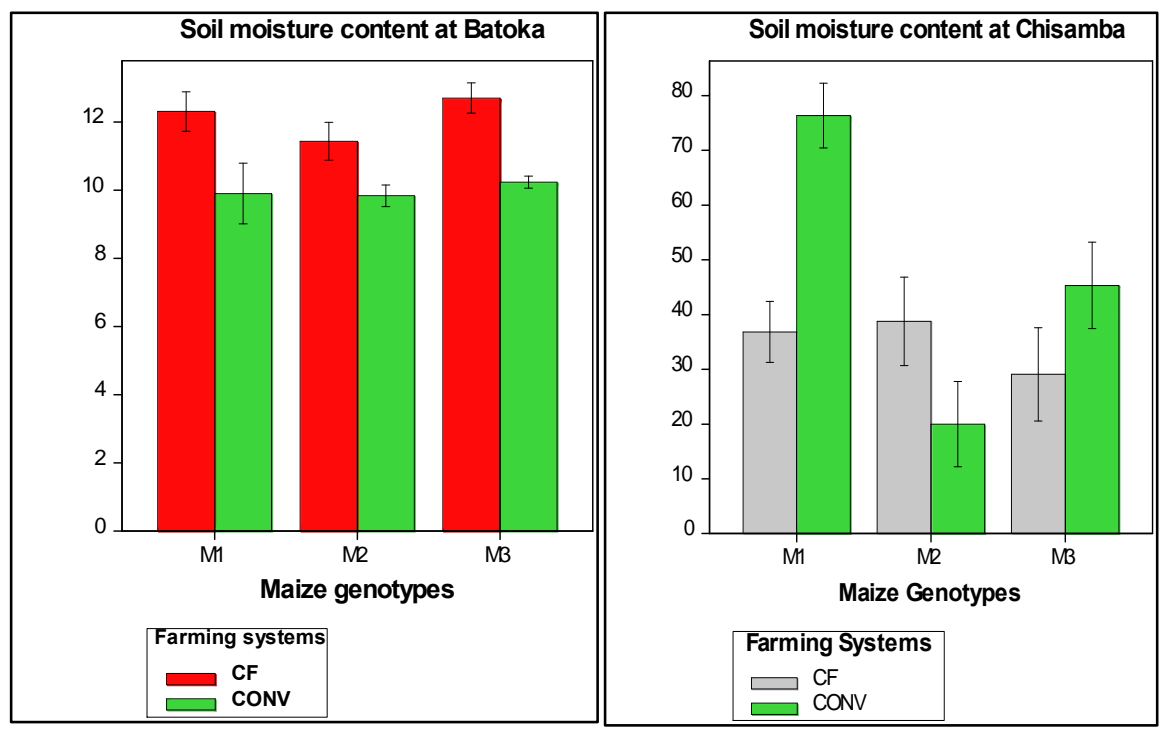

Figure 3. Effect of farming systems on soil moisture content at Batoka $(40 \mathrm{~cm})$ and Chisamba $(40 \mathrm{~cm}) 8$ weeks after planting

Cowpea genotypes used in the experiment for rotation with maize significantly $(\mathrm{P}<0.05)$ contributed to the uptake of moisture in the CF plots. Significant interaction between cowpea and maize genotypes was observed at $\mathrm{P}<0.001)$. The cowpea genotypes Lutembwe and its mutant LT conserved highest moisture content with average of $61.8 \%$ and $57.0 \%$ respectively in the CF system mainly due to high dry biomass yield produced by the two genotypes. The dry biomass acted as mulch to prevent excessive loss of water in the plot before planting and during part of the growing season (Richard \& Marietha, 2007).

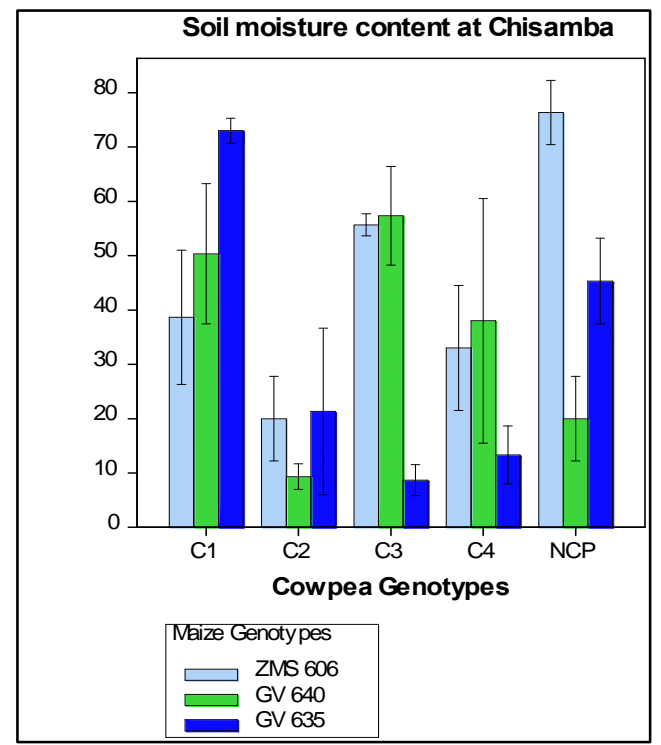

Figure 4. Effect of cowpea genotypes on soil moisture content 


\subsection{Maize Grain Yield $\left(\mathrm{Kg}_{\mathrm{h}} \mathrm{ha}^{-1}\right)$}

On average, between the two sites, Chisamba produced higher maize grain yield $\left(7960 \mathrm{kgha}^{-1}\right)$ than Batoka $\left(4453 \mathrm{kgha}^{-1}\right)$. The differences in maize grain yield between Chisamba and Batoka was as a result of variations in soil quality status. Batoka site is loamy sand soils with low levels of plant nutrients. Maize grain yield in conservation farming (CF) system was $6600 \mathrm{kgha}^{-1}$ and was significantly higher at $\mathrm{P}<0.05$ by $30 \%$ than in conventional farming (CONV) system (Figure 5 and 6). ZMS 606 and GV 640 which yielded $6668 \mathrm{kgha}^{-1}$ and $12000 \mathrm{kgha}^{-1}$ were significantly superior over GV 635 in conservation farming during the 2015/2016 and 2016/2017 growing season respectively. The good performance of maize under CF was attributed to improved soil fertility status that enhanced increased water and nitrogen use efficiency by the crop. Similar results were reported by Sumanta et al. (2013) that maize grain yield increased in the conservation agriculture field after two growing seasons. Golden valley Agricultural Research Trust [GART] (2011) also reported that maize grain yield increased when maize was rotated with a legume crop (mucuna pruriens) in the CF system. Cowpea genotype C4 (BB 14-16-2-2) significantly $(\mathrm{P}<0.05)$ contributed to high yields of maize in the maize - cowpea rotation as compared to other genotypes (Figure 6) mostly due to high Biological Nitrogen Fixation (IAEA, 2008).

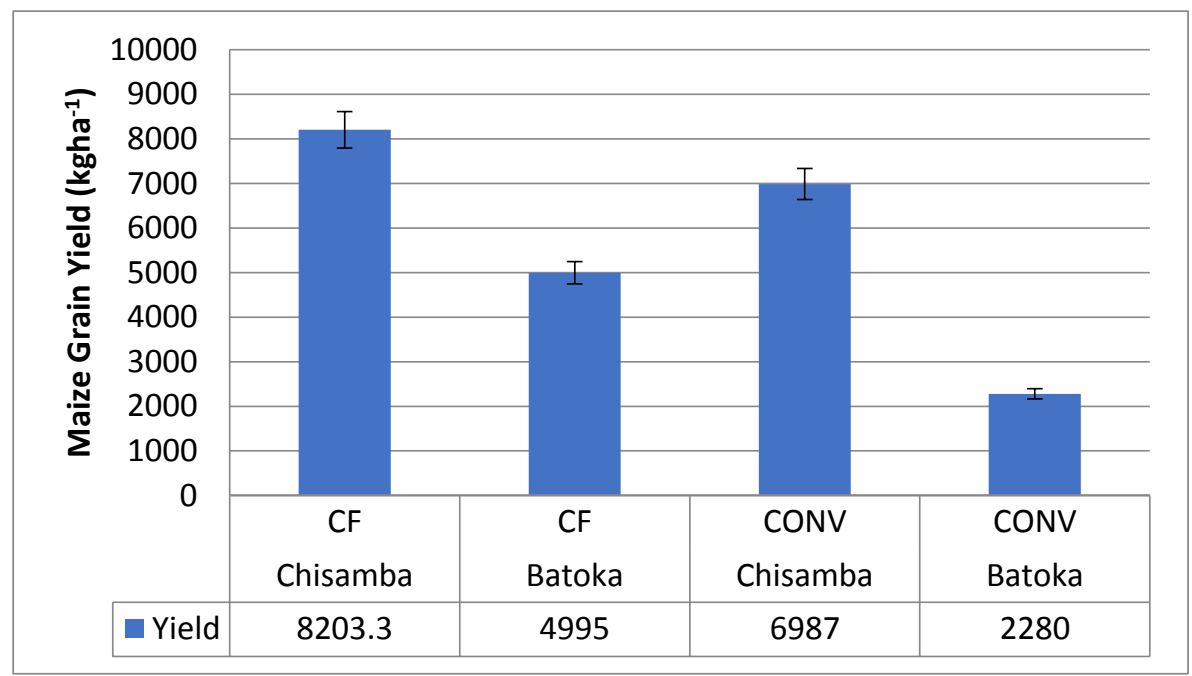

Figure 5. Effect of sites and farming systems (Conservation farming- CF and conventional CONV) on maize grain yield

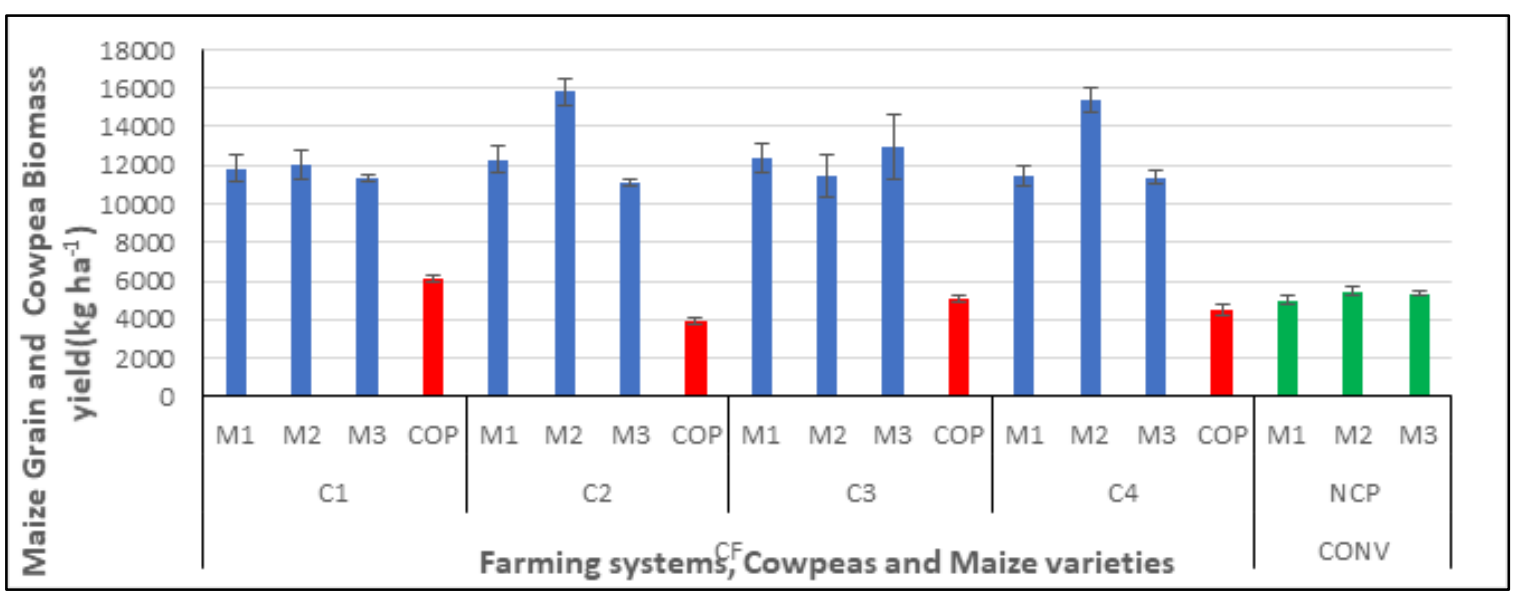

Figure 6. Effect of farming systems and cowpea genotypes on the performance of maize varieties

\section{Conclusion and Recommendations}

Maize grain yields varied according to sites of different soil types. Loamy sandy soils of Batoka produced lower yields than Chisamba with heavy clay loam soils. Conservation Farming system (CF) significantly out yielded conventional farming system (CONV) in maize grain yield for two seasons by $30 \%$ and $60 \%$ due to improved 
soil properties, high nitrogen use efficiency and high moisture utilisation in the CF. Cowpea genotype (Bubebe mutant) BB 14-16-2-2 increased maize yield of ZMS 606 and GV 640 in 2015/16 and 2061/17 growing season under conservation farming system respectively. Cowpea genotype BB 14-16-2-2 can therefore be considered in the maize-cowpea rotation system to improve productivity of ZMS 606 and GV 640 maize varieties for enhanced food security among smallholder farmers in Zambia.

\section{Acknowledgements}

I wish to thank the Agricultural productivity Program for Southern Africa (APPSA) for financial support of the study and International Atomic Energy Agency for provision of ${ }^{15} \mathrm{~N}$ labelled urea and for making arrangements for analysis of $\% \mathrm{~N}$ and atom $\%{ }^{15} \mathrm{~N}$ at the University of Florida in the USA and provision of Diviner 2000 for soil moisture content measurements. The Golden valley Agricultural Research Trust is also appreciated for providing land were the experiment was conducted. The University of Zambia, School of Agricultural sciences (departments of plant science and soils) for their supervision of the $\mathrm{PhD}$ study.

\section{References}

Aagaard. P. J. (2011). The practice of conventional and conservation agriculture in east and southern Africa hand book. Conservation Farming Unit 14-25. Retrieved from https://conservationagriculture.org/.../CONVENTIONAL\%20\%20CA\%20FARMING\%

Baligar, V. C., Fageria, N. K., \& He, Z. L. (2007). Nitrogen Use Efficiency in plants. Communications in Soil Science and Plant Analysis, 32(7-8), 921-950. https://doi.org/10.1081/CSS-100104098

Branson. M. (2010). Using Conservation Agriculture to improve water use efficiency in wheat crops on the Branson farm in South Australia. Retrieved from https://www.slideshare.net/.../using-ca-to-improve-water-use-efficiency-in-wheat-crop.

Cakir, R. (2004). Effect of water stress at different development stages on vegetative and reproductive growth of corn. Field Crops Research, 89, 1-16. http://dx.doi.org/10.1016/j.fcr.2004.01.005

Hamza, M. A., \& Anderson, W. K. (2003). Responses of soil properties and grain yields to deep ripping and gypsum application in a compacted loamy sand soil contrasted with a sandy clay loam soil in Western Australia. Australian Journal of Agricultural Research, 54(3), 273-282. https://doi.org/10.1071/AR02102

Esser, K. B. (2017). Water infiltration and moisture in soils under conservation and conventional agriculture in agro-ecological zone IIa, Zambia. Agronomy, 7(2), 40. https://doi.org/10.3390/agronomy7020040

FAO (2010). Climate Smart Agriculture: Policies, practices and Financing for Food Security, Adaptation and Mitigation. FAO. Rome. Retrieved from www.fao.org/docrep/013/i1881e/i1881e00.htm

FAO (2012). Climate Change Mitigation Finance for Smallholder Agriculture. A guide book to harvest soil carbon sequestration benefits. Retrieved from https://rowman.com/.../Climate-Change-Mitigation-Finance-For-Smallholder-Agricult...

IAPRI (2015). Rural Agricultural Livelihoods survey.2015 Survey Report. Retrieved from www.iapri.org.zm/surveys

IAEA (2008). Use of tracer technology in mineral fertilizer N management. In: Guidelines on Nitrogen Management in Agricultural Systems. Retrieved from https://www-pub.iaea.org/MTCD/publications/PDF/TCS-29_PDF/TCS-29.pdf

Michel, K., \& Patrice, S. (2003). A simulation tool for sustainable freight transport policies. European Journal of Economic and social systems, 16(2), 229-250. Retrieved from https://ideas.repec.org/a/ris/ejessy/0142.html

Peter, R. H., \& Bram, G. (2010). How conservation agriculture can contribute to buffering climate change. In: Mathew P. Reynolds (Ed). Climate Change and Crop Production. CPI Antony Rowe, Chppenham.UK.

Rao, M. R., \& Mathuva, M. N. (2000). Legumes for improving maize yields and income in semi-arid Kenya. Agriculture Ecosystems \& Environment, 78(2), 123-137. https://doi.org/10.1016/S0167-8809(99)00125-5

Richard, S., \& Marietha, O. (2007). Conservation agriculture as practiced in Tanzania: three case studies. Publisher African Conservation Tillage Net work. Retrieved from http://ww.fao.org/fileadmin/user_upload/oed/docs/GCPRAF413GER_2011_ER.pdf.

Steiner, K. (2002). Conservation Tillage-Gateway to Food Security and Sustainable Rural Development. African Conservation Tillage Network. Information Series, 1, 1. Retrieved from 
http://www.act-africa.org/lib.php?com=5\&com2=20\&com3=64\&res_id=76

Tahar, B. (2010). Improvement of Water Use Efficiency in Irrigated Agriculture: A Review. Journal of Agronomy, 9 , 1-8. https://doi.org/10.3923/ja.2010.1.8

Sumanta, K. C. H., Srinivasarao, R. B., Mallick, T., Satyanarayana, R., Prakash, N., Adrian, J., \& Venkateswarlu, B. (2013). Conservation agriculture in maize (Zea mays L.)-horsegram (Macrotyloma uniflorum L.) system in rainfed Alfisols for carbon sequestrationand climate change mitigation. Journal of agrometeorology, 15(special issue-1), 144-149.

Verhulst, N., Govaerts, B., Verachtent, E., Castellanos-Navarrete, A., Mezzalama, M., Wall, P. C., Deckers, J., \& Sayre, K. D. (2010). Conservation Agriculture, improving soil quality for sustainable production systems? In: Lal, R. and Stewart, B. A. (eds) Food security and Soil Quality. CRC Press. Boca Raton, Retrieved from https://www.tandfonline.com/doi/abs/10.1080/07352680902776358

Verhulst, N., François, I., Grahmann, K., Govaerts, B., \& Cox, R. (2014). Nitrogen use efficiency and optimization of nitrogen fertilization in conservation agriculture. CIMMYT. PP 4.

\section{Copyrights}

Copyright for this article is retained by the author(s), with first publication rights granted to the journal.

This is an open-access article distributed under the terms and conditions of the Creative Commons Attribution license (http://creativecommons.org/licenses/by/3.0/). 